\title{
PENERAPAN MEDIA KOMPUTER (SOFTWARE DERIVE 6.0) DALAM UPAYA MENINGKATKAN HASIL BELAJAR MATEMATIKA PADA MATERI AJAR INTEGRAL SISWA KELAS XII IPA SMA DARUL DA'WAH WAL IRSYAD KENDARI
}

\begin{abstract}
ABSTRAK
LA ODE SABRAN, "Penerapan Media Komputer (Software Derive 6.0) dalam Upaya Meningkatkan Hasil Belajar Matematika pada Materi Ajar Integral Siswa Kelas XII IPA SMA Darul' Da'wah Wal Irsyad Kendari."

Penelitian ini adalah Penelitian Tindakan Kelas (PTK). Rumusan masalah dalam penelitian ini adalah apakah hasil belajar matematika siswa pada materi ajar integral dapat ditingkatkan dengan menerapkan komputer (software derive 6.0) sebagai media pembelajaran? Tujuannya adalah melalui penerapan komputer (software derive 6.0) sebagai media pembelajaran pada materi ajar integral, hasil belajar matematika siswa, kelas XII IPA SMA Darul Da'wah Wal Irsyad Kendari dapat ditingkatkan.

Hipotesis tindakan penelitian ini adalah hasil belajar matematika siswa kelas XII IPA SMA DDI Kendari pada materi ajar integral dapat ditingkatkan dengan menerapkan komputer (Software Derive 6.0) sebagai media pembelajaran.

Penelitian ini dilaksanakan pada siswa kelas XII IPA SMA DDI Kendari pada tahun pelajaran 2011/2012 dengan jumlah siswa 21 orang. Instrument yang digunakan adalah tes hasil belajar matematika berupa tes siklus I, tes siklus II dan tes siklus III (setelah pemberian tindakan), lembar observasi guru dan siswa serta rekaman video untuk kondisi pelaksanaan tindakan.

Prosedur penelitian ini terdiri dari: (1) perencanaan, (2) pelaksanaan tindakan, (3) observasi dan evaluasi, dan (4) reflekasi. Pembelajaran diberikan dengan menerapkan komputer (software derive 6.0) sebagai media pembelajaran.

Hasil penelitian ini menunjukkan bahwa melalui penerapan komputer (software derive 6.0) sebagai media pembelajaran, hasil belajar matematika siswa kelas XII IPA SMA DDI Kendari dapat ditingkatkan. Hal ini terlihat dari tercapainya indikator kinerja baik dari segi proses maupun hasil pada penelitian ini yaitu dari segi pelaksanaan skenario pembelajaran oleh guru yang telah disusun, pada siklus I mencapai $77,27 \%$, siklus II 90,9\%, dan pada siklus III mencapai $100 \%$. Begitu pula dengan pelaksanaan pembelajaran yang dilakukan oleh siswa pada siklus I mencapai 85,93\%, siklus II 87,5\%, dan siklus III mencapai $90,62 \%$. Sedangkan dari segi hasil yang berkaitan dengan hasil belajar siswa menunjukkan bahwa pada siklus I mencapai 80,95\% dengan rata-rata 69,42, siklus II 80,95\% dengan nilai rata-rata 71,52 dan pada siklus III meningkat 90, 47\% dengan nilai rata-rata 73,52.
\end{abstract}


LA ODE SABRAN

UNIVERSITAS HALU OLEO

Ld.sabran@uho.ac.id

\section{PENDAHULUAN}

\subsection{Latar Belakang}

Pendidikan sangat berperan penting dalam menjamin kemajuan suatu bangsa ke arah yang lebih baik. Bangsa yang sejahtera sangat ditentukan oleh kualitas pendidikan yang dimiliki oleh masyarakatnya. Tingginya kualitas pendidikan akan melahirkan manusia yang memiliki pengetahuan, nilai dan keterampilan serta pemahaman baru mengenai pengembangan potensi-potensi diri sehingga dapat menjalankan kehidupan dan mampu mengatasi berbagai permasalahan kehidupan yang dihadapinya.

Sumber daya manusia dan mutu pendidikan dapat ditingkatkan melalui pelaksanaan pembelajaran matematika yang berkualitas. Pelaksanaan pembelajaran matematika yang berkualitas sangat penting untuk dilaksanakan, karena matematika merupakan landasan untuk pengembangan ilmu pengetahuan dan teknologi. Selain itu, matematika juga dapat melatih siswa untuk berpikir secara logis, rasional, operasional dan terukur sesuai dengan karakteristik ilmu, sehingga matematika yang diajarkan di sekolah harus dikuasai dan dipahami sedini mungkin oleh siswa. Penguasaan siswa terhadap konsep matematika dapat dilihat dari prestasi belajar yang telah dicapai siswa untuk mata pelajaran matematika.

Mutu dan kualitas pendidikan di Indonesia masih jauh dari yang diharapkan, apalagi jika dibandingkan dengan mutu pendidikan di Negara lain. Hasil Survey Political and Economic Risk Consultancy (PERC) yang dilakukan pada tahun 2007 tentang mutu pendidikan di kawasan Asia, menempatkan Indonesia di rangking 12 setingkat di bawah Vietnam (Hadis, 2010: 1). Merosotnya mutu pendidikan di Indonesia secara umum mengakibatkan rendahnya Sumber Daya Manusia (SDM) Indonesia. Survey tentang Human Development Index (HDI) oleh United Nation Development Program (UNDP) pada tahun 2009 menunjukkan bahwa Sumber Daya Manusia Indonesia berada di urutan 113 dari 177 negara di dunia (Brodjonegoro dalam Hadis, 2010: 2).

Kualitas pendidikan yang belum memuaskan juga ditunjukkan oleh hasil belajar matematika siswa yang sangat rendah. Menurut penelitian Trends in International Mathematics and Science Study (TIMSS) tahun 2007, matematika Indonesia berada di peringkat ke-41 berada jauh dibawah Palestina sebagai Negara berkecamuk dari segi keamanan yang menduduki urutan ke 34. Sekolah Menengah Atas Darud Da'wah wal Irsyad Kendari sebagai salah satu lembaga pendidikan formal juga merasakan adanya penurunan hasil belajar siswa terutama dalam pelajaran matematika. 
LA ODE SABRAN

UNIVERSITAS HALU OLEO

Ld.sabran@uho.ac.id

Peneliti kemudian melakukan observasi dan wawancara di SMA Darul Da'wah wal Irsyad Kendari pada tanggal 25 Februari 2011. Hasil observasi dan wawancara tersebut mengungkapkan bahwa siswa mengalami kesulitan dalam memahami materi pelajaran matematika yang bersifat abstak seperti integral. Siswa kurang tertarik belajar matematika dan menganggapnya sangat sulit. Bahkan simbol-simbol pelajaran matematika seperti integral dianggap sebagai sesuatu yang sangat rumit. Hasil wawancara singkat dengan beberapa orang siswa, pada umumnya mereka mengatakan bahwa pada pembahasan materi integral mereka sulit memahaminya karena sifatnya yang abstrak dan tidak ada media yang bisa menunjukkan secara konkrit serta membuat mereka tertarik dalam memahami setiap konsep atau defenisi yang berkaitan dengan materi integral. Hal ini menyebabkan sebagian besar siswa merasa malas untuk belajar matematika. Mereka menganggap matematika sangat sulit dan membosankan.

Tindakan yang dapat dilakukan untuk memperbaiki hasil belajar siswa adalah adanya upaya penanganan proses pembelajaran matematika terutama penggunaan media yang dapat memudahkan siswa dalam memahami materi pelajaran matematika. Siswa yang menganggap matematika sebagai sesuatu yang rumit sehingga menyebabkan siswa malas untuk belajar dapat lebih tertarik dan termotivasi dalam belajar melalui penggunaan media pembelajaran secara tepat. Daya tarik belajar yang tinggi akan melahirkan siswa yang tekun dan rajin dalam belajar, sehingga ketuntasan pembelajaran yang diharapkan dapat tercapai.

Media komputer dapat digunakan untuk membantu siswa dalam belajar matematika. Keterlibatan siswa secara aktif dan kreatif dalam menggunakan komputer akan membuat siswa lebih tertarik dan termotivasi belajar matematika sehingga akan menunjang siswa dalam melihat dan memahami secara konkrit dari konsep matematika yang bersifat abstrak. Pemanfaatan media komputer disini, dilakukan dengan menggunakan software matematika derive 6.0 dalam proses pembelajaran matematika. Software komputer dapat digunakan sebagai alat pengajaran untuk mengeksplorasi, menyelidiki, menyelesaikan masalah, berinteraksi, merefleksi, bernalar, berkomunikasi, dan belajar banyak konsep yang sesuai kurikulum sekolah (Afgani dkk, 2008: 46)

\subsection{Rumusan Masalah}

Berdasarkan latar belakang di atas, maka rumusan masalah dalam penelitian ini adalah "apakah proses pembelajaran matematika dapat terlaksana dengan baik dan hasil belajar matematika siswa pada materi ajar integral dapat ditingkatkan dengan menerapkan komputer (software derive 6.0) sebagai media pembelajaran?" 
LA ODE SABRAN

UNIVERSITAS HALU OLEO

Ld.sabran@uho.ac.id

\subsection{Manfaat}

Manfaat yang diharapkan dapat diperoleh dari penelitian tindakan kelas ini adalah:

1. Bagi siswa, agar melalui pembelajaran dengan menggunakan media komputer diharapkan siswa memiliki usaha yang keras untuk memahami konsep dalam matematika sehingga permasalahan-permasalahan matematika dapat dipahami dan diselesaikan dengan baik yang pada akhirnya dapat meningkatkan hasil belajar siswa khususnya pada pokok bahasan integral.

2. Bagi guru, dapat memperluas wawasan dan pengetahuan guru dalam pemanfaatan komputer sebagai media pembelajaran dalam upaya meningkatkan hasil belajar siswa, khususnya memudahkan siswa dalam memahami hal yang bersifat abstrak.

3. Bagi sekolah, sebagai bahan masukan dalam upaya meningkatkan mutu dan kualitas pembelajaran matematika.

\section{KAJIAN PUSTAKA}

\subsection{Proses Pembelajaran Matematika}

Seseorang yang mengartikan belajar sebagai menghafal fakta akan lain cara mengajarnya dibandingkan dengan orang yang mengartikan belajar sebagai proses perubahan tingkah laku. Sehingga, penting artinya memahami pengertian belajar tersebut. Kimble dalam Simanjuntak (1992: 38) belajar adalah perubahan yang relatif menetap dalam potensi tingkah laku yang terjadi sebagai akibat dari latihan dengan penguatan dan tidak termasuk perubahanperubahan karena kematangan, kelelahan atau kerusakan pada susunan saraf.

Slameto (1988: 2) menjelaskan bahwa belajar ialah suatu proses usaha yang dilakukan individu untuk memperoleh suatu perubahan tingkah laku yang baru secara keseluruhan, sebagai hasil pengalaman individu itu sendiri dalam interaksi dengan lingkungannya. Klien dalam Semiawan (2002: 4) mendefenisikan belajar sebagai suatu proses eksperiensial (pengalaman) yang menghasilkan perubahan perilaku yang relatif permanen dan yang tidak dapat dijelaskan dengan keadaan sementara kedewasaan atau tendensi ilmiah.

Belajar dapat pula diartikan sebagai perubahan tingkah laku pada diri individu berkat adanya interaksi antara individu dengan individu dan individu dengan lingkungannya sehingga mereka lebih mampu berinteraksi dengan lingkungan sekitarnya. Perubahan tingkah laku ini bukan disebabkan oleh proses pertumbuhan yang bersifat fisiologis. Perubahan yang terjadi karena belajar dapat berupa perubahan-perubahan dalam kebiasaan (habit), kecakapankecakapan (skills), atau dalam ketiga aspek yakni pengetahuan (kognitif), sikap (afektif), dan 
LA ODE SABRAN

UNIVERSITAS HALU OLEO

Ld.sabran@uho.ac.id

keterampilan (psikomotor). Kegiatan belajar merupakan kegiatan pokok dalam proses pendidikan sehingga berhasil tidaknya pencapaian tujuan pendidikan tergantung pada bagaimana proses belajar yang dialami oleh peserta didik (Usman, 2001: 44-45).

Berdasarkan pendapat para ahli di atas maka dapat dipahami bahwa belajar adalah proses perubahan tingkah laku ke arah yang lebih baik yang terjadi secara sadar pada diri seseorang yang diperoleh dari pengalaman secara berulang-ulang dalam lingkungannya sehingga dapat meningkatkan kemampuan kognitif, afektif, psikomotor serta kemampuan lainnya sebagai manusia.

Pemahaman akan pengertian dan pandangan guru terhadap pembelajaran akan mempengaruhi peranan dan aktivitasnya dalam mengajar. Sebaliknya, aktivitas guru dalam mengajar serta aktivitas siswa dalam belajar sangat bergantung pula pada pemahaman guru terhadap mengajar. Mengajar merupakan suatu usaha mengorganisasi lingkungan dalam hubungannya dengan anak didik dan bahan pengajaran sehingga menimbulkan proses belajar pada diri siswa (Usman, 2001: 46).

William, H dalam Thonthowi (1993: 98) menyatakan bahwa mengajar adalah upaya dalam memberi stimulus, bimbingan, pengarahan dan dorongan kepada siswa agar terjadi proses belajar. Bahan pelajaran hanya merupakan perangsang dan tindakan guru hanya merupakan tindakan memberi dorongan. Menurut Sardiman (2007: 47) mengajar pada dasarnya merupakan suatu usaha untuk menciptakan kondisi atau sistem lingkungan yang mendukung dan memungkinkan untuk berlangsungnya proses belajar.

Pembelajaran pada hakekatnya adalah melakukan kegiatan belajar, sehingga proses pembelajaran dapat berlangsung secara efektif dan efisien ( Suryosubroto, 2003: 19). Selanjutnya Alvin Howard mendefenisikan mengajar sebagai suatu aktivitas untuk mencoba menolong, membimbing seseorang untuk mendapatkan, mengubah atau mengembangkan keahlian (skill), sikap (attitudes), cita-cita (ideals), penghargaan (appreciations), dan pengetahuan (knowledge). Maksudnya bahwa guru harus mampu membawa perubahan yang baik untuk mengubah tingkah laku siswa (Slameto, 1988: 33)

Mengacu pada pendapat para ahli tentang mengajar, maka dapat dikatakan bahwa mengajar merupakan suatu aktivitas yang direncanakan untuk membimbing dan mengarahkan siswa dalam proses pembelajaran, sehingga siswa dapat memperoleh pengalaman dan pengetahuan yang mampu mengantarkan siswa pada perubahan tingkah laku yang lebih baik meliputi segi keahlian, sikap, cita-cita, pengetahuan dan kompetensikompetensi lainnya sebagai manusia. 
LA ODE SABRAN

UNIVERSITAS HALU OLEO

Ld.sabran@uho.ac.id

Matematika berasal dari bahasa latin manthanein atau mathema yang berarti belajar atau hal yang dipelajari. Matematika dalam bahasa Belanda disebut wiskunde atau ilmu pasti yang kesemuanya berkaitan dengan penalaran. Matematika adalah suatu pengetahuan tertua yang terbentuk dari penelitian bilangan dan ruang. Matematika adalah suatu disiplin ilmu yang berdiri sendiri dan tidak merupakan cabang dari ilmu pengetahuan alam. Matematika merupakan alat dan bahasa dasar banyak ilmu. Jonhson dalam Abdurrahman (2003: 252) menjelaskan bahwa matematika adalah bahasa simbolis yang fungsi praktisnya untuk mengekspresikan hubungan-hubungan kuantitatif dan keruangan sedangkan fungsi teoritisnya adalah untuk memudahkan berpikir.

Palling menjelaskan bahwa ide manusia tentang matematika berbeda-beda tergantung pada pengalaman dan pengetahuan masing-masing orang. Ada yang mengatakan bahwa matematika hanya perhitungan yang mencakup tambah, kurang, kali, dan bagi, tetapi ada pula yang melibatkan topik-topik seperti aljabar, geometri dan trigonometri. Banyak pula yang beranggapan bahwa matematika mencakup segala sesuatu yang berkaitan dengan berpikir logis. Selanjutnya, Palling mengemukakan bahwa matematika adalah suatu cara untuk menemukan jawaban terhadap masalah yang dihadapi manusia, suatu cara menggunakan informasi, menggunakan pengetahuan tentang bentuk dan ukuran, menggunakan pengetahuan tentang menghitung, dan yang paling penting adalah memikirkan dalam diri manusia itu sendiri dalam melihat dan menggunakan hubungan-hubungan (Abdurrahman, 2003: 252).

Berdasarkan definisi yang diuraikan para ahli di atas, maka matematika dapat diartikan sebagai disiplin ilmu yang mempelajari cara-cara berhitung, mempelajari aljabar, geometri, dan trigonometri serta arah berpikir yang logis yang saling berkaitan untuk menyelesaikan masalah yang dihadapi manusia dalam kehidupannya melalui penggunaan hubungan-hubungan pengetahuan tersebut.

Pembelajaran merupakan proses komunikasi dua arah yang terdiri dari kegiatan mengajar dilakukan oleh pihak guru dan kegiatan belajar dilakukan oleh pihak murid. Undang-undang Sistem Pendidikan Nasional No. 20 tahun 2003 menyatakan Pembelajaran adalah proses interaksi peserta didik dengan pendidik dan sumber belajar pada suatu lingkungan belajar. Pembelajaran (instruction), merupakan akumulasi dari konsep mengajar (teaching) dan konsep belajar (learning). Penekanannya pada perpaduan antara. keduanya, yakni kepada penumbuhan aktivitas subjek didik. Konsep tersebut dapat dipandang sebagai suatu sistem, sehingga dalam sistem belajar ini terdapat komponen siswa atau peserta didik, 
LA ODE SABRAN

UNIVERSITAS HALU OLEO

Ld.sabran@uho.ac.id

tujuan, materi untuk mencapai tujuan, fasilitas dan prosedur serta alat atau media yang harus dipersiapkan (Muhidin, 2011: 3).

Pembelajaran dapat diartikan sebagai proses yang membuat terjadinya proses belajar yang menghasilkan suatu perubahan (Moeslichatoen dalam Indrayanto: 2011, online). Sebuah proses pembelajaran yang baik, paling tidak harus melibatkan 3 aspek, yaitu : aspek psikomotorik, aspek kognitif dan aspek afektif. Aspek psikomotorik dapat difasilitasi lewat adanya praktikum-praktikum dengan tujuan terbentuknya keterampilan eksperimental. Aspek kognitif difasilitas lewat berbagai aktifitas penalaran dengan tujuan adalah terbentuknya penguasaan intelektual. Sedangkan aspek afektif dilakukan lewat aktifitas pengenalan dan kepekaan lingkungan dengan tujuan terbentuknya kematangan emosional (Prayudi, 2007: 1).

Pembelajaran matematika dapat diartikan sebagai suatu proses atau cara membelajarkan siswa terhadap materi pelajaran matematika. Proses ini dikatakan efektif apabila terjadi transfer belajar yaitu materi pelajaran matematika yang disajikan dapat diserap ke dalam struktur kognitif siswa yang belajar. Hudoyo (1988: 5) menjelaskan bahwa pada proses belajar matematika, ada beberapa karakteristik dari matematika yang perlu diperhatikan yaitu (1) objek matematika yang bersifat abstrak , (2) materi matematika yang disusun secara hierarkis, (3) cara penalaran matematika adalah deduktif. Karena matematika bersifat hierarkis dan terstruktur, maka dalam belajar matematika tidak boleh terputus-putus serta harus memperhatikan urutan materi.

Berdasarkan pemaparan di atas dapat diketahui bahwa proses pembelajaran matematika adalah merupakan suatu proses yang berlangsung dua arah melalui interaksi antara guru dan siswa dalam pembelajaran matematika dengan tujuan adanya pemberian pemahaman konsep matematika dari guru kepada siswa melalui pengalaman dan latihan serta pembimbingan sehingga siswa dapat berpikir secara logis dan sistematis.

\subsection{Hasil Belajar Matematika}

Hasil belajar digolongkan ke dalam tiga aspek: (1) Pengetahuan (Knowledge); perubahan yang diharapkan adalah dari tidak mengetahui menjadi mengetahui, dari tidak mengerti menjadi mengerti, (2) Keterampilan (skill); perubahan yang diharapkan dari tidak terampil menjadi terampil, dari tidak dapat melakukan, membuat, menjadi dapat melakukan, membuat, dan (3) Sikap (attitude); perubahan yang diharapkan adalah dari sikap negatif menjadi positif, dari sikap salah menjadi sikap yang baik (Thonthowi, A, 1993: 100). 
LA ODE SABRAN

UNIVERSITAS HALU OLEO

Ld.sabran@uho.ac.id

Hasibuan (1986: 6) juga mengungkapkan bahwa hasil belajar siswa dapat dilihat pada tiga ranah siswa yaitu: perubahan pada ranah kognitif, umpamanya dari belum atau tidak jelas menjadi jelas, dari belum atau tidak dapat menjawab sampai dapat menjawab secara benar, dari belum atau tidak mengerti peran yang harus dimainkan sampai dapat berperan secara aktif (ranah psikomotor), dari bersikap acuh tak acuh menjadi penuh perhatian (ranah efektif), dari menentang secara kasar pendapat teman dalam diskusi-diskusi kelompok menjadi dapat mentoleransi pendapat teman yang tidak sejalan dengan dirinya (ranah efektif), dari kurang terampil bertanya atau memimpin diskusi kelompok menjadi terampil bertanya atau memimpin diskusi kelompok (ranah psikomotor).

Berdasarkan pandangan di atas, dapat dikatakan bahwa hasil belajar matematika siswa adalah kemampuan intelektual yang dimiliki siswa setelah ia menerima pengalaman belajarnya baik berupa perhitungan matematis maupun penalaran matematis yang dapat dilihat dari berkembangnya kemampuan kognitif, afektif, dan psikomotor.

\subsection{Pengertian dan Manfaat Media Pembelajaran}

AECT(Association of Education and Communication Technology) di Amerika membatasi media sebagai segala bentuk dan saluran yang digunakan orang untuk menyalurkan pesan atau informasi. NEA (National Education Association) mengatakan bahwa media adalah bentuk-bentuk komunikasi baik cetak maupun audio-visual serta peralatannya. Kaitannya dengan pendidikan, media pembelajaran adalah sarana pendidikan yang dapat digunakan sebagai perantara dalam proses pembelajaran untuk mempertinggi efektifitas dan efisiensi dalam mencapai tujuan pengajaran (Sanaky, 2011: 3 -4).

Livie dalam Sanaky (2011: 6 - 7) menjelaskan bahwa penggunaan media diharapkan mampu membawa fungsi positif bagi siswa yaitu:

a. Fungsi atensi, artinya media visual merupakan inti, menarik dan mengarahkan perhatian pembelajar untuk berkonsentrasi pada isi pelajaran.

b. Fungsi afektif, artinya media visual dapat terlihat dari tingkat kenikmatan pembelajar ketika belajar membaca teks bergambar.

c. Fungsi kognitif, artinya media visual mengungkapkan bahwa lambang visual memperlancar pencapaian tujuan untuk memahami informasi atau pesan yang terkandung dalam gambar.

d. Fungsi kompensatoris artinya media visual memberikan konteks untuk memahami teks membantu pembelajar yang lemah dalam membaca. 
LA ODE SABRAN

UNIVERSITAS HALU OLEO

Ld.sabran@uho.ac.id

Berdasarkan pandangan di atas, dapat diketahui bahwa media pembelajaran adalah sarana yang digunakan dalam proses pembelajaran yang berfungsi sebagai alat yang mampu memperlancar kegiatan pembelajaran secara efektif dan efisien sehingga pesan atau informasi yang ingin disampaikan pada kegiatan belajar dapat diterima oleh siswa secara maksimal. Penggunaan media pembelajaran akan membuat siswa lebih berkonsentrasi pada pelajaran dan dapat meningkatkan kemampuan kognitif, afektif dan psikomotor siswa.

\subsection{Keunggulan Komputer (Software Derive 6.0) sebagai Media Pembelajaran Efektif}

Kelebihan media komputer adalah memberikan kesempatan kepada siswa untuk berinteraksi dalam bentuk mempengaruhi atau mengubah urutan yang disajikan. Komputer dapat memberi siswa pengalaman kinestetik melalui penggunaan keyboard komputer (Hamalik, 2003: 235 - 236).

Thorn dalam Sanaky (2011: 181 - 182) mengajukan enam kriteria untuk menilai komputer sebagai media pembelajaran yang efektif dan interaktif, yaitu:

a. Kemudahan navigasi, artinya sebuah program media harus dirancang sesederhana, serapi dan seindah mungkin,

b. Ada kandungan kognisi,

c. Pengetahuan dan presentasi informasi,

d. Integrasi media, yaitu media yang digunakan mampu mengintegrasikan aspek tujuan pembelajaran, materi yang harus dipelajari, variasi metode yang digunakan dan kemampuan sipembelajar.

e. Menarik minat pembelajar,

f. Fungsi secara keseluruhan, artinya program yang dikembangkan memberikan pembelajaran yang diinginkan pembelajar.

Lee dalam Ariani (2010: 147 - 148) menjelaskan paling sedikit ada delapan alasan pemakaian komputer sebagai media pembelajaran yaitu: pengalaman, motivasi, meningkatkan pembelajaran, materi yang otentik, interaksi yang lebih luas, local goverment and society, lebih pribadi, tidak terpaku pada sumber tunggal, dan pemahaman global. Pembelajaran dengan komputer akan memberikan motivasi yang lebih tinggi karena komputer selalu dikaitkan dengan kesenangan, permainan dan kreativitas. Sehingga kualitas pembelajaran dapat lebih meningkat. Selain itu, pembelajaran dengan komputer juga akan memberi kesempatan pada pembelajar untuk mendapat materi pembelajaran yang otentik dan dapat berinteraksi secara lebih luas. Pembelajaran pun menjadi lebih bersifat pribadi yang akan memenuhi kebutuhan strategi pembelajaran yang berbeda-beda. 
LA ODE SABRAN

UNIVERSITAS HALU OLEO

Ld.sabran@uho.ac.id

\subsection{Materi Integral}

Integral merupakan suatu objek matematika yang dapat diinterpretasikan sebagai luas wilayah. Proses menemukan integral suatu fungsi disebut sebagai pengintegralan. Integral dibagi menjadi dua, yaitu: integral tertentu dan integral tak tentu. Notasi matematika yang digunakan untuk menyatakan integral adalah $\int$ seperti huruf $\mathrm{S}$ yang memanjang (S singkatan dari "Sum" yang berarti penjumlahan). Integral tentu didefenisikan:

Diberikan suatu fungsi $f$ bervariabel real $x$ dan interval antara $[\mathrm{a}, \mathrm{b}]$ pada garis real, integral tertentu:

$$
\int_{a}^{b} f(x) d x
$$

Secara informal didefenisikan sebagai luas wilayah pada bidang xy yang dibatasi oleh kurva grafik $f$, sumbu-X, dan garis vertikal $x=a$ dan $x=b$. Pada notasi integral di atas: $a$ adalah batas bawah dan $b$ adalah batas atas yang menentukan domain pengintegralan, $f$ adalah integran yang akan dievaluasi terhadap $x$ pada interval $[\mathrm{a}, \mathrm{b}]$, dan $d x$ adalah variabel pengintegralan.

Pendefenisian formal integral tertentu, definisikan sebagai integral Riemann, yaitu limit dari penjumlahan Riemann. Misalkanlah kita hendak mencari luas daerah yang dibatasi oleh fungsi $f$ pada interval tertutup [a, b]. Dalam mencari luas daerah tersebut, interval [a, b] dapat kita bagi menjadi banyak subinterval yang lebarnya tidak perlu sama dan kita memilih sejumlah $n$-1 titik $\left\{x_{1}, x_{2}, x_{3}, \ldots, x_{n-1}\right\}$ antara $a$ dengan $b$ sehingga memenuhi hubungan:

$$
\alpha=x_{0} \leq x_{1} \leq x_{2} \leq \cdots \leq x_{n-1} \leq x_{n}=b
$$

Himpunan $P=\left\{x_{0}, x_{1}, x_{2}, \ldots, x_{n-1}, x_{n}\right\}$ kita sebut sebagai partisi [a, b], yang membagi $[\mathrm{a}, \mathrm{b}]$ menjadi sejumlah $n$ subinterval $\left[x_{0}, x_{1}\right],\left[x_{1}, x_{2}\right], \ldots,\left[x_{n-1}, x_{n}\right]$. Lebar subinterval pertama $\left[x_{0}, x_{1}\right]$ kita nyatakan sebagai $\Delta x_{1}$, lebar ke- $i$ kita nyatakan sebagai $\Delta x_{i}$ $=x_{i}-x_{i-1}$. Pada tiap subinterval inilah kita pilih suatu titik sembarang dan pada subinterval ke- $i$ tersebut kita memilih titik sembarang $x_{i}$. Maka pada tiap-tiap subinterval akan terdapat batangan persegi panjang yang lebarnya $\Delta x$ dan tingginya berawal dari sumbu $x$ sampai menyentuh titik $\left(x, f\left(x_{i}\right)\right)$ pada kurva. Apabila kita menghitung luas tiap-tiap batangan tersebut dengan mengalikan $f\left(x_{i}\right) . \Delta x_{i}$ dan menjumlahkan keseluruhan luas daerah batangan tersebut, kita akan dapatkan: $\quad S_{p}=\sum_{i=1}^{n} f\left(x_{i}\right) \cdot \Delta x_{i}$

Secara cermat, definisi integral tertentu sebagai limit dari penjumlahan Riemann adalah:

Andaikan bahwa $P, \Delta x_{i}$, dan $x_{i}$. Mempunyai arti seperti yang dibahas di atas, tetapkan juga $\|P\|$, disebut norma $P$, menyatakan jumlah selang bagian yang terpanjang dari partisi $P$. Andaikan $f$ suatu fungsi yang dideinisikan pada selang tutup [a, b]. Jika 
LA ODE SABRAN

UNIVERSITAS HALU OLEO

Ld.sabran@uho.ac.id

$$
\lim _{\|P\| \rightarrow 0} \sum_{i=1}^{n} f\left(x_{i}\right) \cdot \Delta x_{i}
$$

Ada, kita katakan bahwa $f$ adalah terintegralkan pada [a, b]. Lebih lanjut $\int_{a}^{b} f(x) d x$, disebut integral tentu (atau integral Riemann) $f$ dari $a$ ke $b$, diberikan oleh

$$
\int_{a}^{b} f(x) d x=\lim _{\|P\| \rightarrow 0} \sum_{i=1}^{n} f\left(x_{i}\right) \cdot \Delta x_{i}
$$

Kesamaan

$$
\lim _{\|P\| \rightarrow 0} \sum_{i=1}^{n} f\left(x_{i}\right) \cdot \Delta x_{i}=L
$$

Berarti bahwa berpadanan terhadap setiap $\varepsilon>0$, terdapat suatu $\delta>0$, sedemikian sehingga

$$
\left|\sum_{i=1}^{n} f\left(x_{i}\right) \Delta x_{i}-L\right|<\varepsilon
$$

Untuk semua jumlah Riemann $\sum_{i=1}^{n} f\left(x_{i}\right) \cdot \Delta x_{i}$ untuk $f$ pada [a, b] untuk mana norma $\|P\|$ dari partisi yang berhubungan adalah lebih kecil dari $\delta$. Dalam hal ini, kita katakan bahwa limit yang ditunjukkan itu ada dan bernilai L (Purcell dan Varberg, 1987: 276 - 278).

\subsection{Hipotesis Tindakan}

Berdasarkan kajian teori dan kerangka pemikiran maka hipotesis tindakan penelitian ini adalah hasil belajar matematika siswa kelas XII IPA SMA DDI Kendari pada materi ajar integral dapat di tingkatkan dengan menerapkan komputer (Software Derive 6.0) sebagai media pembelajaran. 
LA ODE SABRAN

UNIVERSITAS HALU OLEO

Ld.sabran@uho.ac.id

\section{METODE PENELITIAN}

\subsection{Jenis Penelitian}

Penelitian ini termasuk dalam penelitian tindakan kelas (PTK). Purwadi dalam Sukidin (2008: 10) menjelaskan penelitian tindakan kelas (yang selanjutnya disingkat PTK) adalah suatu bentuk penelitian yang dilaksanakan oleh guru untuk memecahkan masalah yang dihadapi dalam melaksanakan tugas pokoknya, yaitu mengelola pelaksanaan kegiatan belajar mengajar (KBM). Penelitian tindakan kelas dilakukan dengan jalan merencanakan perbaikan, melaksanakan tindakan, serta mengamati dan melakukan refleksi tindakan secara kolaboratif dan partisipatif demi meningkatkan hasil belajar siswa.

\subsection{Waktu dan Tempat Penelitian}

Penelitian ini dilaksanakan pada semester ganjil tahun ajaran 2011/2012, yakni tanggal 22 September 2011 sampai 15 Oktober 2011 di kelas XII IPA SMA Darud Da'wah wal Irsyad Kendari.

\subsection{Subjek Penelitian}

Subjek dalam penelitian ini adalah siswa kelas XII IPA Sekolah Menengah Atas Darud Da'wah wal Irsyad Kendari dengan jumlah siswa sebanyak 21 orang yang terdiri dari 7 orang laki-laki dan 14 orang perempuan .

\subsection{Instrumen Penelitian}

Instrumen yang digunakan dalam penelitian ini tidak diuji validitas maupun reliabilitasnya. Adapun instrumen yang digunakan dalam penelitian ini adalah:

1. Lembar observasi, untuk memperoleh data tentang kondisi pelaksanaan pembelajaran matematika dengan menggunakan komputer sebagai media pembelajaran.

2. Tes hasil belajar matematika, untuk memperoleh data tentang kemampuan atau hasil belajar siswa setelah diterapkan komputer sebagai media pembelajaran, khususnya pada materi pembelajaran integral.

3. Jurnal refleksi diri, untuk memperoleh data tentang refleksi diri. Jurnal utamanya berisi catatan tentang hal-hal yang menurut guru belum tercapai dalam pembelajaran serta kesulitan-kesulitan guru ketika pembelajaran berlangsung sehingga dapat diminimalisir pada pembelajaran berikutnya.

4. Rekaman video, sebagai sumber data tentang proses pembelajaran guru dan siswa yang dapat digunakan untuk membandingkan hasil pengamatan observer dan jurnal refleksi guru. 
LA ODE SABRAN

UNIVERSITAS HALU OLEO

Ld.sabran@uho.ac.id

\subsection{Prosedur Penelitian}

Penelitian tindakan kelas ini akan dilaksanakan sebanyak tiga siklus dengan tiap siklus dilaksanakan sesuai dengan perubahan yang ingin dicapai pada faktor-faktor yang diteliti. Berdasarkan observasi awal dan diskusi dengan guru bidang studi matematika, ditetapkan bahwa tindakan yang digunakan untuk meningkatkan hasil belajar matematika khususnya pada materi ajar integral adalah memberikan pembelajaran dengan menggunakan komputer (Software derive 6.0) sebagai media pembelajaran. Proses pelaksanaan digambarkan dalam bentuk spiral, sebagai berikut:

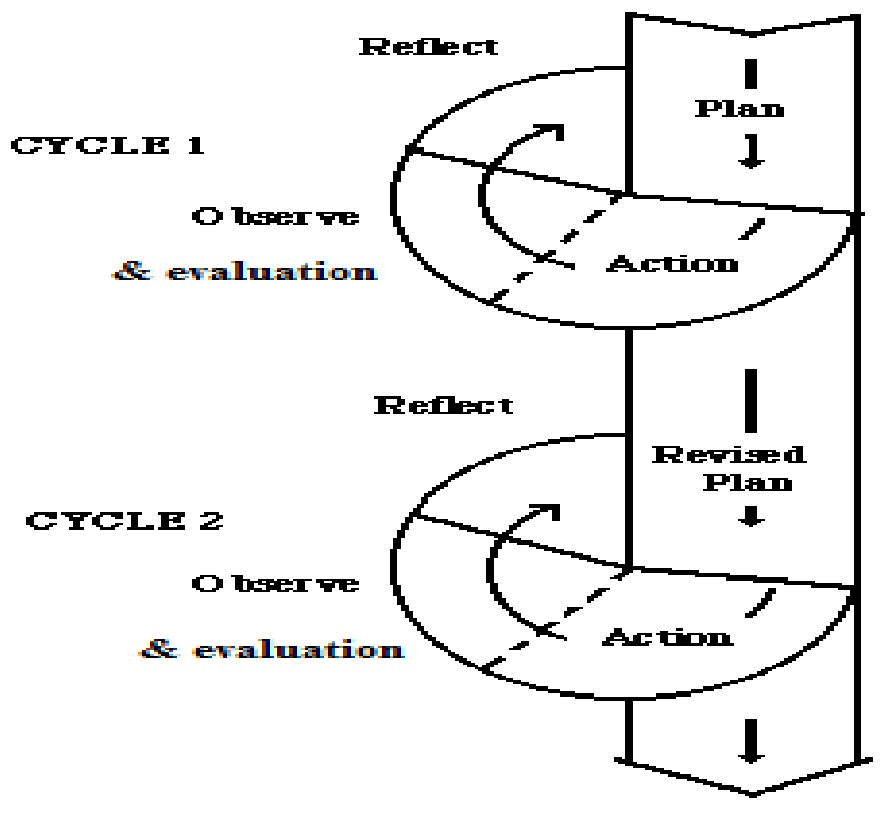

Gambar. Proses Dasar Penelitian Tindakan Kelas

(Dikutip dari MacIsaac 1996 dalam Emzir, 2003: 240)

Adapun tindakan tersebut mengikuti prosedur penelitian tindakan kelas berikut yaitu: (1) perencanaan, (2) pelaksanaan tindakan, (3) pelaksanaan observasi dan evaluasi, serta (4) refleksi.

Secara rinci prosedur penelitian tindakan kelas ini di uraikan sebagai berikut:

a. Perencanaan, kegiatan yang dilakukan pada tahap ini meliputi:

1. Membuat perencanaan pembelajaran

2. Membuat lembar observasi, untuk melihat kondisi proses pembelajaran dikelas ketika melaksanakan pembelajaran dengan menggunakan media komputer.

3. Membuat alat bantu pembelajaran yang diperlukan dalam rangka membantu siswa lebih memahami materi pelajaran yang diajarkan. 
LA ODE SABRAN

UNIVERSITAS HALU OLEO

Ld.sabran@uho.ac.id

4. Membuat alat evaluasi untuk melihat hasil belajar matematika siswa dengan menggunakan komputer sebagai media pembelajaran.

5. Membuat jurnal untuk mengetahui refleksi diri.

b. Pelaksanaan tindakan, kegiatan yang dilaksanakan pada tahap ini adalah melaksanakan rencana pembelajaran yang telah dibuat. Pada tahap ini juga dilakuka observasi terhadap pelaksanaan tindakan dan melakukan evaluasi.

c. Refleksi, pada tahap ini dilakukan perenungan mengenai proses pembelajaran yang dilaksanakan kemudian dicocokkan dengan hasil observasi dan evaluasi pada tahap sebelumnya. Kemudian dari hasil tersebut peneliti dan guru akan mendiskusikan ketercapaian proses pembelajaran yang dilaksanakan dan jika terdapat kelemahankelemahan atau kekurangan yang terjadi pada siklus sebelumnya akan diperbaiki pada siklus selanjutnya.

\subsection{Data dan Teknik Pengumpulan Data}

a. Sumber data: Data bersumber dari siswa dan guru berupa tes hasil belajar siswa dan proses pelaksanaan tindakan siswa dan guru ketika pembelajaran menggunakan media komputer diterapkan.

b. Jenis data:

1. Data kuantitatif diperoleh melalui tes hasil belajar

2. Data kualitatif berupa pelaksanaan pembelajaran diperoleh dari lembar observasi terhadap guru dan lembar observasi terhadap siswa dan jurnal refleksi guru.

c. Teknik pengambilan data

1. Data mengenai pelaksanaan pembelajaran menggunakan komputer (Software derive 6.0) sebagai media pembelajaran diambil dengan menggunakan lembar observasi.

2. Data mengenai hasil belajar siswa diambil dengan menggunakan tes hasil belajar.

3. Data tentang refleksi diri diambil melalui perenungan mengenai pelaksanaan proses pembelajaran yang dilaksnakan kemudian dimasukan ke dalam jurnal.

\subsection{Indikator Kinerja}

Indikator keberhasilan dalam penelitian ini ada dua macam, yaitu indikator tentang maksimalnya pelaksanaan proses pembelajaran menggunakan media komputer dan indikator pencapaian hasil belajar matematika siswa. Indikator tersebut adalah sebagai berikut:

1. Indikator proses pembelajaran dikatakan terlaksana dengan baik apabila minimal $85 \%$ dari rencana pelaksanaan pembelajaran dengan penerapan komputer sebagai media pembelajaran terlaksana dengan baik oleh guru dan siswa. 
LA ODE SABRAN

UNIVERSITAS HALU OLEO

Ld.sabran@uho.ac.id

2. Pembelajaran dengan menggunakan media komputer dikatakan berhasil apabila minimal $85 \%$ siswa telah mencapai kentutasan belajar secara individu dengan memperoleh nilai $\geq 63$ (standar sekolah).

\section{HASIL DAN PEMBAHASAN}

\subsection{Hasil Penelitian}

\subsubsection{Deskripsi Ketuntasan Proses Pelaksanaan Pembelajaran Oleh Guru Pada Setiap} Tindakan Siklus

Tabel 1.

Ketuntasan Proses Pelaksanaan Pembelajaran Oleh Guru Pada Setiap Tindakan Siklus

\begin{tabular}{|c|c|c|c|}
\hline Tindakan & $\begin{array}{c}\text { Pertemuan I } \\
(\%)\end{array}$ & $\begin{array}{c}\text { Pertemuan II } \\
(\%)\end{array}$ & $\begin{array}{c}\text { Pertemuan III } \\
(\%)\end{array}$ \\
\hline Siklus I & 81,81 & 81,81 & 77,27 \\
\hline Siklus II & 81,81 & 90,9 & \\
\hline Siklus III & 90,9 & 100 & \\
\hline
\end{tabular}

Langkah-langkah pembelajaran yang tidak dilaksanakan oleh guru menurut pengamatan observer yaitu:

a. Langkah-langkah pembelajaran yang tidak terlaksana pada siklus I

Pertemuan Pertama

1. Guru tidak menyampaikan tujuan pembelajaran

2. Guru tidak memberikan motivasi belajar kepada siswa

3. Guru tidak mempersilahkan kelompok lain untuk memberikan tanggapan.

4. Guru tidak mengecek pemahaman siswa mengenai materi yang dipelajari dengan memberikan soal yang dikerjakan secara individu oleh masing-masing siswa.

\section{Pertemuan Kedua}

1. Guru tidak memberikan motivasi belajar kepada siswa.

2. Guru tidak memberikan kesempatan kepada siswa untuk memahami permasalahan dalam LKS.

3. Guru tidak memberikan kesempatan bertanya kepada siswa mengenai kejelasan isi LKS.

4. Guru tidak mengarahkan siswa untuk membuat rangkuman pembelajaran.

$>$ Pertemuan Ketiga

1. Guru tidak memberikan apersepsi terkait materi yang akan dibahas melalui tanya jawab. 
LA ODE SABRAN

UNIVERSITAS HALU OLEO

Ld.sabran@uho.ac.id

2. Guru tidak member penjelasan pengantar mengenai materi yang akan dipelajari dengan memanfaatkan computer sebagai media

3. Guru tidak memberikan kesempatan siswa untuk memahami permasalahan dalam LKS.

4. Guru tidak berkeliling kelas dan memantau siswa dalam menyelesaikan permasalahan dalam LKS baik secara manual maupun menggunakan komputer.

5. Guru tidak mengecek pemahaman siswa mengenai materi yang dipelajari melalui soal yang dikerjakan secara individu oleh masing-masing siswa.

b. Langkah-langkah pembelajaran yang tidak terlaksana pada siklus II

$>$ Pertemuan Pertama

1. Guru tidak memberikan motivasi belajar kepada siswa.

2. Guru tidak memberi penjelasan pengantar mengenai materi yang akan dipelajari dengan memanfaatkan komputer sebagai media.

3. Guru tidak memberi kesempatan bertanya kepada siswa mengenai kejelasan isi LKS

4. Guru tidak memberi kesempatan kepada siswa untuk memahami petunjuk dalam LKS mengenai pemanfaatan komputer sebagai media pembelajaran.

$>$ Pertemuan Kedua

1. Guru tidak memberi kesempatan kepada siswa untuk memahami petunjuk dalam LKS mengenai pemanfaatan komputer sebagai media pembelajaran.

2. Guru tidak menganalisa dan mengevaluasi ragam presentasi jawaban siswa mengenai permasalahan dalam LKS.

c. Langkah-langkah pembelajaran yang tidak terlaksana pada siklus III

Pertemuan Pertama

1. Guru tidak menyiapkan peserta didik secara psikis dan fisik untuk mengikuti proses pembelajaran.

2. Guru tidak memberi kesempatan kepada siswa untuk memahami petunjuk dalam LKS mengenai pemanfaatan komputer sebagai media pembelajaran.

\section{$>$ Pertemuan Kedua}

Hasil pengamatan observer pada pertemuan ini menunjukkan bahwa langkah-langkah pelaksanaan pembelajaran sesuai dengan rencana perbaikan penbelajaran yang telah disusun dengan menerapkan komputer sebagai media pembelajaran semua dapat tercapai. Keseluruhan langkah-langkah pembelajaran telah dilakukan oleh guru. 
LA ODE SABRAN

UNIVERSITAS HALU OLEO

Ld.sabran@uho.ac.id

4.1.2. Deskripsi Ketuntasan Proses Pelaksanaan Pembelajaran Oleh Siswa Pada Setiap Tindakan Siklus

Tabel 2.

Ketuntasan Proses Pelaksanaan Pembelajaran Oleh Siswa Pada Setiap Tindakan Siklus

\begin{tabular}{|c|c|c|c|}
\hline Tindakan & $\begin{array}{c}\text { Pertemuan I } \\
(\%)\end{array}$ & $\begin{array}{c}\text { Pertemuan II } \\
(\%)\end{array}$ & $\begin{array}{c}\text { Pertemuan III } \\
(\%)\end{array}$ \\
\hline Siklus I & $75 \%$ & $78,12 \%$ & $85,93 \%$ \\
\hline Siklus II & $85,93 \%$ & $87,5 \%$ & \\
\hline Siklus III & $89,06 \%$ & $90,62 \%$ & \\
\hline
\end{tabular}

\subsubsection{Deskripsi Jurnal Refleksi Guru Pada Setiap Tindakan Siklus}

Tabel 3.

Jurnal Refleksi Guru Pada Setiap Tindakan Siklus

\begin{tabular}{|c|c|c|c|}
\hline Tindakan & $\begin{array}{c}\text { Pertemuan I } \\
(\%)\end{array}$ & $\begin{array}{c}\text { Pertemuan II } \\
(\%)\end{array}$ & $\begin{array}{c}\text { Pertemuan III } \\
(\%)\end{array}$ \\
\hline Siklus I & $86,36 \%$ & $77,27 \%$ & $77,27 \%$ \\
\hline Siklus II & $86,36 \%$ & $90,9 \%$ & \\
\hline Siklus III & $95,45 \%$ & $100 \%$ & \\
\hline
\end{tabular}

Langkah-langkah pembelajaran yang tidak dilaksanakan oleh guru menurut hasil refleksi guru yaitu:

a. Langkah-langkah pembelajaran yang tidak terlaksana pada siklus I

Pertemuan Pertama

1. Guru tdak menyampaikan tujuan pembelajaran.

2. Guru tidak memberikan motivasi belajar kepada siswa.

3. Guru tidak mengecek pemahaman siswa mengenai materi yang dipelajari dengan memberikan soal yang dikerjakan secara individu oleh masing-masing siswa.

Pertemuan Kedua

1. Guru tidak memberi apersepsi terkait materi yang akan dibahas melalui tanya jawab

2. Guru tidak memberikan motivasi belajar kepada siswa.

3. Guru tidak memberikan kesempatan kepada siswa untuk memahami permasalahan dalam LKS.

4. Guru tidak memberi kesempatan bertanya kepada siswa mengenai kejelasan isi LKS.

5. Guru tidak mengarahkan siswa untuk membuat rangkuman pembelajaran 
LA ODE SABRAN

UNIVERSITAS HALU OLEO

Ld.sabran@uho.ac.id

$>$ Pertemuan Ketiga

1. Guru tidak memberi apersepsi terkait materi yang akan dibahas melalui tanya jawab.

2. Guru tidak memberi penjelasan pengantar mengenai materi yang akan dipelajari dengan memanfaatkan komputer sebagai media.

3. Guru tidak memberi kesempatan siswa untuk memahami permasalahan dalam LKS.

4. Guru tidak berkeliling kelas dan memantau siswa dalam menyelesaikan permasalahan dalam LKS baik secara manual maupun menggunakan komputer.

5. Guru tidak mengecek pemahaman siswa mengenai materi yang dipelajari melalui soal yang dikerjakan secara individu oleh masing-masing siswa.

b. Langkah-langkah pembelajaran yang tidak terlaksana pada siklus II

Pertemuan Pertama

1. Guru tidak memberikan motivasi belajar kepada siswa.

2. Guru tidak memberi penjelasan pengantar mengenai materi yang akan dipelajari dengan memanfaatkan komputer sebagai media.

3. Guru tidak memberi kesempatan kepada siswa untuk memahami petunjuk dalam

LKS mengenai pemanfaatan komputer sebagai media pembelajaran

Pertemuan Kedua

1. Guru tidak memberi kesempatan kepada siswa untuk memahami petunjuk dalam LKS mengenai pemanfaatan komputer sebagai media pembelajaran.

2. Guru tidak menganalisa dan mengevaluasi ragam presentasi jawaban siswa mengenai permasalahan dalam LKS.

c. Langkah-langkah pembelajaran yang tidak terlaksana pada siklus III

Pertemuan Pertama

1. Guru tidak memberi kesempatan kepada siswa untuk memahami petunjuk dalam LKS mengenai pemanfaatan komputer sebagai media pembelajaran.

$>$ Pertemuan Kedua

Hasil refleksi guru pada pertemuan ini adalah langkah-langkah pembelajaran dengan menerapkan komputer sebagai media pembelajaran semua dapat tercapai.

\subsubsection{Deskripsi Ketuntasan Hasil Belajar Matematika Siswa}

Tabel 4.

Ketuntasan Hasil Belajar Matematika Siswa

\begin{tabular}{|l|c|c|c|}
\hline \multicolumn{1}{|c|}{ Uraian } & Tes Siklus I & Tes Siklus II & Tes Siklus III \\
\hline Ketuntasan Secara Klasikal & $80,95 \%$ & $80,95 \%$ & $90,47 \%$ \\
\hline Rata-rata Siswa & 69,42 & 71,52 & 73,52 \\
\hline
\end{tabular}


LA ODE SABRAN

UNIVERSITAS HALU OLEO

Ld.sabran@uho.ac.id

\subsection{Pembahasan Hasil Penelitian}

\subsubsection{Tindakan Siklus I}

\section{a. Pertemuan Pertama}

Hasil analisis antara pengamat dan guru menunjukkan adanya perbedaan, yaitu pengamat menyatakan bahwa langkah yang dilakukan oleh guru hanya mencapai 18 langkah yang telah dilakukan, sedangkan menurut guru sendiri langkah yang telah dilakukan mencapai 19 langkah, sehingga terjadi perbedaan 1 langkah. Perbedaan yang dimaksud yaitu menurut hasil pengamatan observer, guru tidak mempersilahkan kelompok lain untuk memberikan tanggapan atas presentasi kelompok penyaji dalam diskusi. Namun, menurut guru langkah ini telah dilakukan.

Pengamat dan guru melakukan diskusi untuk menentukan atau mengambil keputusan langkah-langkah apa saja yang sebenarnya tidak dilakukan oleh guru, sehingga dari hasil diskusi tersebut dapat ditentukan langkah-langkah pembelajaran yang akan menjadi perbaikan pada pertemuan selanjutnya. Guru mencoba mengingat kembali tentang langkah dimana guru mempersilahkan kelompok lain (siswa) untuk memberikan tanggapan atas presentasi kelompok penyaji. Dari hasil renungannya guru merasa pada langkah ini guru tidak mempersilahkan siswa untuk memberikan tanggapan. Setelah kelompok penyaji menampilkan hasil diskusi kelompoknya, guru langsung menganalisa dan mengevaluasi ragam penyelesaian yang ditampilkan siswa tanpa terlebih dahulu mempersilahkan kelompok lain untuk memberikan tanggapan. Hasil perenungan guru tersebut kemudian didiskusikan bersama-sama dengan pengamat. Agar data lebih akurat, guru dan pengamat kemudian secara bersama-sama membandingkan data hasil perenungan guru, observasi pengamat dan rekaman video yang dilakukan pada saat proses pembelajaran berlangsung. Setelah melakukan diskusi dan mengamati rekaman video pelaksanaan pembelajaran, maka disepakati bahwa langkah dimana guru mempersilahkan siswa untuk menanggapi hasil diskusi kelompok tidak dilakukan oleh guru, sehingga menjadi tujuan perbaikan pembelajaran pada pertemuan berikutnya. Langkah-langkah itu adalah:

1. Guru menyampaikan tujuan pembelajaran.

2. Guru memberikan motivasi belajar kepada siswa.

3. Guru memberi kesempatan kepada kelompok lain untuk memberikan tanggapan

4. Guru mengecek pemahaman siswa mengenai materi yang dipelajari dengan memberikan soal yang dikerjakan secara individu oleh masing-masing siswa. 
LA ODE SABRAN

UNIVERSITAS HALU OLEO

Ld.sabran@uho.ac.id

Berdasarkan hasil analisis deskriptif ketuntasan proses pelaksanaan pembelajaran oleh siswa untuk pertemuan pertama pada Tabel 2 dapat dilihat bahwa ketuntasan proses pembelajaran siswa mencapai $75 \%$ yang berarti bahwa hasil pengamatan observer langkahlangkah pembelajaran yang dilakukan oleh siswa berdasarkan rencana pelaksanaan dan lembar observasi yang telah dibuat hanya 75\% dari 16 langkah yang dilakukan oleh keseluruhan siswa. Antusias siswa yang masih rendah dalam belajar disebabkan karena kurang maksimalnya guru dalam melaksanakan langkah-langkah pembelajaran yang telah direncanakan. Sehingga langkah pembelajaran yang tidak dilakukan oleh guru berpengaruh pada antusias siswa dalam belajar, seperti guru tidak memotivasi siswa dalam belajar menyebabkan banyak siswa yang kurang bersemangat dalam belajar. Hal ini menjadi perhatian guru dan merupakan tujuan perbaikan pada pembelajaran berikutnya.

Berdasarkan hasil pengamatan observer maupun guru pada pertemuan ini, dapat disimpulkan bahwa proses pelaksanaan pembelajaran yang dilakukan dengan menerapkan komputer sebagai media pembelajaran masih kurang maksimal dilakukan oleh guru maupun siswa. Masih banyak langkah-langkah pembelajaran yang belum terlaksana. Hasil diskusi antara pengamat dan guru serta rekaman video pembelajaran yang dilakukan menunjukkan bahwa terdapat 4 langkah yang belum dilakukan. Begitu pula pembelajaran yang dilakukan oleh siswa masih membutuhkan banyak bimbingan dan arahan dari guru sehingga mereka lebih bersemangat dan antusias lagi dalam belajar. Hasil diskusi mengungkapkan bahwa beberapa kesulitan guru diantaranya adalah guru masih kaku mengajar didepan kelas dan belum terbiasa mengajar siswa menggunakan media komputer yang mengakibatkan rendahnya perhatian siswa dalam belajar. Kelemahan-kelemahan tersebut akan diperbaiki guru pada pertemuan selanjutnya.

\section{b. Pertemuan Kedua}

Hasil analisis antara pengamat dan guru menunjukkan adanya perbedaan, yaitu pengamat menyatakan bahwa langkah yang dilakukan oleh guru mencapai 18 langkah yang telah dilakukan, sedangkan menurut guru sendiri langkah-langkah pembelajaran yang telah dilakukan hanya mencapai 17 langkah, sehingga terjadi perbedaan 1 langkah. Perbedaan yang dimaksud yaitu menurut hasil pengamat, guru memberi apersepsi terkait materi yang akan dibahas melalui tanya jawab kepada siswa. Namun, menurut guru langkah ini tidak dilakukan.

Pengamat dan guru melakukan diskusi untuk menentukan atau mengambil keputusan langkah-langkah pembelajaran apa saja yang sebenarnya tidak dilakukan oleh guru, sehingga 
LA ODE SABRAN

UNIVERSITAS HALU OLEO

Ld.sabran@uho.ac.id

dari hasil diskusi tersebut dapat ditentukan langkah-langkah pembelajaran yang akan menjadi perbaikan pada pertemuan selanjutnya. Guru kemudian mengingat kembali langkah ketika guru tidak memberi apersepsi terkait materi yang akan dibahas melalui tanya jawab kepada siswa. Hasil perenungan guru adalah guru menjelaskan bahwa ia merasa tidak memberikan apersepsi kepada siswa, namun pengamat menjelaskan bahwa guru sudah melakukan langkah pembelajaran tersebut. Guru dan pengamat kemudian sepakat untuk menggunakan sumber informasi yang ketiga yaitu rekaman video pembelajaran yang dilakukan pada pertemuan kedua untuk mengambil keputusan mengenai pelaksanaan apersepsi oleh guru. Hasil diskusi guru dan pengamat setelah menonton rekaman video pada pertemuan kedua ditetapkan bahwa guru memberikan apersepsi terkait materi yang akan dipelajari, sehingga tidak menjadi tujuan perbaikan pembelajaran pada pertemuan berikutnya. Dengan demikian langkah-langkah pembelajaran yang menjadi tujuan perbaikan pembelajaran pada pertemuan selanjutnya terdiri dari 4 langkah, yaitu:

1. Guru memberikan motivasi belajar kepada siswa.

2. Guru memberi kesempatan siswa untuk memahami permasalahan dalam LKS.

3. Guru memberi kesempatan bertanya kepada siswa mengenai kejelasan isi LKS.

4. Guru mengarahkan siswa untuk membuat rangkuman pembelajaran.

Berdasarkan hasil analisis deskriptif ketuntasan proses pelaksanaan pembelajaran oleh siswa untuk pertemuan kedua pada Tabel 2 dapat dilihat bahwa ketuntasan proses pelaksanaan pembelajaran siswa mencapai $78,12 \%$ yang berarti bahwa hasil pengamatan observer langkah-langkah pembelajaran yang dilakukan oleh siswa berdasarkan rencana pelaksanaan dan lembar observasi yang telah dibuat mencapai 78,12\% dari 16 langkah yang dilakukan oleh keseluruhan siswa. Lebih meningkat dari pertemuan sebelumnya. Walaupun peningkatan antusias siswa dalam melakukan proses pembelajaran belum meningkat secara signifikan, tetapi siswa lebih aktif dalam melakukan pembelajaran menggunakan media komputer bila dibandingkan dengan pertemuan sebelumnya. Secara perlahan guru juga semakin meningkatkan peran siswa dalam pembelajaran. Kelemahan guru pada saat pembelajaran yang berimbas pada belum maksimalnya proses pembelajaran yang dilakukan siswa adalah guru tidak memberikan motivasi belajar sehingga siswa masih kurang bersemangat dalam belajar, guru tidak memberikan kesempatan kepada siswa untuk bertanya dan memahami isi LKSnya sehingga siswa masih terlihat bingung dalam menyelesaikan permasalahan dalam LKS. Selain itu, diakhir pembelajaran guru tidak mengarahkan siswa untuk membuat rangkuman pembelajaran sehingga siswa tidak dapat menarik kesimpulan 
LA ODE SABRAN

UNIVERSITAS HALU OLEO

Ld.sabran@uho.ac.id

dari pembelajaran yang dilakukan pada pertemuan kedua. Kelemahan-kelemahan tersebut menjadi perhatian guru dan merupakan tujuan perbaikan pembelajaran pada pertemuan selanjutnya sehingga siswa lebih aktif dalam melakukan proses pembelajaran.

Hasil pengamatan observer maupun guru pada pertemuan ini menggambarkan bahwa proses pelaksanaan pembelajaran yang dilakukan dengan menerapkan komputer sebagai media pembelajaran masih kurang maksimal dilakukan oleh guru dan siswa. Masih banyak langkah-langkah pembelajaran yang belum dilaksanakan oleh guru dan keaktifan siswa dalam melaksanakan proses pembelajaran masih sangat rendah. Hal ini terlihat dari proses pelaksanaan pembelajaran yang dilakukan oleh guru masih sama dengan pertemuan sebelumnya dan siswa baru mencapai $78,12 \%$. Hasil diskusi antara guru dan pengamat mengungkapkan bahwa pada pertemuan ini masih banyak kendala yang dirasakan guru sehingga langkah-langkah yang belum tercapai pada pertemuan sebelumnya sudah dapat dilakukan, tetapi langkah-langkah lainnya yang sudah tercapai pada pertemuan sebelumnya justru tidak dilakukan. Guru mengungkapkan masih canggung mengajar didepan kelas dengan menerapkan komputer sebagai media pembelajaran. Tetapi, pada pertemuan berikutnya guru akan lebih berusaha lagi untuk melaksanakan pembelajaran dengan sebaikbaiknya.

c. Pertemuan Ketiga

Hasil analisis antara pengamat dengan guru menunjukkan hasil yang sama yaitu langkah yang dilakukan oleh guru hanya mencapai 17 langkah dari 22 langkah yang telah ditetapkan, sehingga pada pertemuan ini tidak ada perbedaan antara pengamat dan guru. Meskipun tidak terjadi perbedaan antara guru dan pengamat dalam mengamati proses pelaksanaan pembelajaran, namun diskusi masih tetap dilakukan oleh guru dan pengamat agar proses pembelajaran menjadi lebih baik dan langkah-langkah pembelajaran yang belum tercapai dijadikan sebagai tujuan perbaikan pembelajaran pada pertemuan selanjutnya.

Berdasarkan diskusi antara pengamat dengan guru maka disepakati bahwa ada 5 langkah yang akan menjadi tujuan perbaikan pada pertemuan berikutnya. Langkah-langkah tersebut adalah:

1. Guru memberi apersepsi terkait materi yang akan dibahas melalui tanya jawab.

2. Guru memberi penjelasan pengantar mengenai materi yang akan dipelajari dengan memanfaatkan komputer sebagai media.

3. Guru memberi kesempatan siswa untuk memahami permasalahan dalam LKS. 
LA ODE SABRAN

UNIVERSITAS HALU OLEO

Ld.sabran@uho.ac.id

4. Guru berkeliling kelas dan memantau siswa dalam menyelesaikan permasalahan dalam

LKS baik secara manual maupun menggunakan komputer.

5. Guru mengecek pemahaman siswa mengenai materi yang dipelajari melalui soal yang dikerjakan secara individu oleh masing-masing siswa.

Berdasarkan hasil analisis deskriptif ketuntasan proses pelaksanaan pembelajaran oleh siswa untuk pertemuan ketiga pada Tabel 2 dapat dilihat bahwa ketuntasan proses pembelajaran siswa mencapai $85,93 \%$ yang berarti bahwa hasil pengamatan observer langkah-langkah pembelajaran yang dilakukan oleh siswa berdasarkan rencana pelaksanaan dan lembar observasi yang telah dibuat mencapai 85,93\% dari 16 langkah yang dilakukan oleh keseluruhan siswa. Lebih meningkat dari pertemuan sebelumnya yang hanya mencapai $78,12 \%$. Siswa lebih aktif dalam melakukan pembelajaran menggunakan media komputer bila dibandingkan dengan pertemuan sebelumnya. Secara perlahan guru semakin meningkatkan peran siswa dalam pembelajaran dan siswa juga mulai merasakan peran media komputer dalam menampilkan maksud dari materi matematika khususnya integral dengan menggunakan software derive. Masih terdapat beberapa langkah pada pertemuan ini yang menjadi perhatian guru agar menjadi perbaikan pada proses pembelajaran yang dilakukan oleh siswa untuk pertemuan selanjutnya yaitu siswa mendapatkan apersepsi dan penjelasan pengantar dari guru serta pemberian soal individu untuk diselesaikan oleh siswa pada akhir pembelajaran.

Hasil pengamatan observer maupun guru pada pertemuan ini menggambarkan bahwa proses pelaksanaan pembelajaran yang dilakukan dengan menerapkan komputer sebagai media pembelajaran masih kurang maksimal dilakukan oleh guru. Pada pertemuan ini proses pembelajaran yang dilakukan oleh guru justru mengalami penurunan bila dibandingkan dengan pertemuan sebelumnya, sehingga menjadi motivasi guru untuk lebih memperbaiki kualitas pembelajaran. Berbeda halnya dengan proses pembelajaran yang dilakukan oleh siswa yang mengalami peningkatan pada pertemuan ini bila dibandingkan dengan pertemuan sebelumnya.. Guru menjelaskan bahwa pada pertemuan ini guru lebih banyak mengarahkan siswa sehingga guru sendiri kurang maksimal melaksnakan langkah-langkah pembelajaran dan mengalami penurunan. Dengan demikian, disimpulkan bahwa tindakan pada siklus I ini siswa sudah maksimal dalam melakasanakan proses pembelajaran dengan menerapkan komputer sebagai media pembelajaran terlihat dari nilai pencapai ketuntasan proses pembelajaran yaitu $85,93 \%$, dengan indikator kinerja yang ditentukan dalam penelitian ini 
LA ODE SABRAN

UNIVERSITAS HALU OLEO

Ld.sabran@uho.ac.id

telah tercapai. Sedangkan untuk proses pembelajaran guru masih harus lebih ditingkatkan agar mencapai indikator kinerja yang telah ditetapkan.

d. Evaluasi

Hasil evaluasi siklus I menunjukkan bahwa siswa yang memperoleh nilai minimal 63 adalah sebanyak 17 siswa atau sebesar $80,95 \%$ dengan nilai rata-rata 69,42. Hal ini berarti bahwa dari 21 siswa kelas XII IPA, sebanyak 17 orang siswa telah mencapai ketuntasan belajar secara klasikal.

\subsubsection{Tindakan Siklus II}

a. Pertemuan Pertama

Hasil analisis antara pengamat dan guru menunjukkan adanya perbedaan, yaitu pengamat menyatakan bahwa langkah yang dilakukan oleh guru hanya mencapai 18 langkah yang telah dilakukan, sedangkan menurut guru sendiri langkah yang telah dilakukan mencapai 19 langkah, sehingga terjadi perbedaan 1 langkah. Perbedaan yang dimaksud yaitu menurut hasil pengamat, guru tidak memberi kesempatan bertanya kepada siswa mengenai kejelasan isi LKS tetapi menurut guru langkah ini sudah dilakukan.

Pengamat dan guru melakukan diskusi untuk menentukan atau mengambil keputusan langkah-langkah pembelajaran apa saja yang sebenarnya tidak dilakukan oleh guru, sehingga dari hasil diskusi tersebut dapat ditentukan langkah-langkah pembelajaran yang akan menjadi perbaikan pada pertemuan selanjutnya. Guru mencoba mengingat kembali tentang langkah ketika guru tidak memberi kesempatan bertanya kepada siswa mengenai kejelasan isi LKS. Dari hasil renungannya guru merasa pada langkah ini guru telah memberi kesempatan bertanya kepada siswa mengenai kejelasan isi LKS. Setelah mendengarkan pertanyaan siswa, guru kemudian memberikan penjelasan mengenai isi LKS yang berkaitan dengan rumus umum integral subtitusi. Hasil renungan guru tersebut kemudian didiskusikan dengan pengamat. Agar data lebih akurat, guru dan pengamat kemudian secara bersama-sama membandingkan data hasil perenungan guru, observasi pengamat dan rekaman video yang dilakukan pada saat proses pembelajaran berlangsung. Setelah melakukan diskusi dan mengamati rekaman video pelaksanaan pembelajaran, maka disepakati bahwa langkah dimana guru tidak memberi kesempatan bertanya kepada siswa mengenai kejelasan isi LKS ternyata dilakukan oleh guru, sehingga tidak menjadi tujuan perbaikan pada pertemuan berikutnya. Sehingga disepakati ada 3 langkah yang akan menjadi tujuan perbaikan pada pertemuan berikutnya. Langkah-langkah tersebut adalah:

1. Guru memberikan motivasi belajar kepada siswa. 
LA ODE SABRAN

UNIVERSITAS HALU OLEO

Ld.sabran@uho.ac.id

2. Guru memberi penjelasan pengantar mengenai materi yang akan dipelajari dengan memanfaatkan komputer sebagai media.

3. Guru memberi kesempatan kepada siswa untuk memahami petunjuk dalam LKS mengenai pemanfaatan komputer sebagai media pembelajaran.

Hasil pengamatan observer dan guru pada pertemuan ini menyimpulkan bahwa proses pembelajaran yang dilakukan dengan menerapkan komputer sebagai media pembelajaran sudah maksimal dilakukan oleh guru dan siswa. Guru mengungkapkan bahwa pada pertemuan ini guru sudah lebih terbiasa melakukan dan mengarahkan siswa dalam langkahlangkah pembelajaran matematika dengan menerapkan komputer sebagai media pembelajaran. Namun, meskipun pada pertemuan ini langkah-langkah pembelajaran telah dilaksanakan dengan baik, guru belum merasa puas dan akan berusaha lebih baik lagi pada pertemuan berikutnya.

b. Pertemuan Kedua

Hasil analisis antara pengamat dengan guru menunjukkan hasil yang sama yaitu langkah-lankah pembelajaran yang dilakukan oleh guru mencapai 20 langkah dari 22 langkah yang telah dilakukan, sehingga pada pertemuan ini tidak ada perbedaan antara pengamat dan guru. Meskipun tidak terjadi perbedaan antara guru dan pengamat dalam mengamati proses pembelajaran, namun diskusi masih tetap dilakukan oleh guru dan pengamat agar proses pelaksanaan pembelajaran menjadi lebih baik dan langkah-langkah yang belum tercapai dijadikan sebagai tujuan perbaikan pembelajaran pada pertemuan selanjutnya.

Berdasarkan diskusi antara pengamat dengan guru maka disepakati bahwa ada 2 langkah yang akan menjadi tujuan perbaikan pada pertemuan berikutnya. Langkah-langkah tersebut adalah:

1. Guru memberi kesempatan kepada siswa untuk memahami petunjuk dalam LKS mengenai pemanfaatan komputer sebagai media pembelajaran.

2. Guru menganalisa dan mengevaluasi ragam presentasi jawaban siswa mengenai permasalahan dalam LKS.

Hasil pengamatan observer dan guru pada pertemuan ini menyimpulkan bahwa proses pembelajaran yang dilakukan dengan menerapkan komputer sebagai media pembelajaran sudah lebih maksimal dilaksanakan oleh guru dan siswa. Hal tersebut terlihat dari hasil diskusi antara guru dan pengamat pada pertemuan ini yang mengungkapkan bahwa hanya 2 langkah pembelajaran yang belum dilaksanakan oleh guru dari 22 langkah pembelajaran. Hasil diskusi tersebut juga mengungkapkan bahwa guru tidak mengalami kendala-kendala 
LA ODE SABRAN

UNIVERSITAS HALU OLEO

Ld.sabran@uho.ac.id

yang berarti pada saat proses pembelajaran berlangsung dan siswa lebih antusias mengikuti arahan guru karena siswa merasa lebih asik dan lebih mudah memahami pelajaran dengan menerapkan komputer sebagai media pembelajaran. Sehingga dapat disimpulkan bahwa pada tindakan siklus II ini guru dan siswa sudah maksimal melaksanakan proses pembelajaran dengan menerapkan komputer sebagai media pembelajaran. Hal ini terlihat dari pencapai ketuntasan proses pembelajaran oleh guru dan siswa yaitu proses pembelajaran guru mencapai 90,9\% dan pembelajaran oleh siswa mencapai 87,5\%. Pencapaian proses pembelajaran tersebut telah mencapai indikator kinerja yang telah ditetapkan dalam penelitian ini. Namun demikian, guru masih akan berusaha semaksimal mungkin agar pertemuan yang selanjutnya dapat lebih baik lagi dari pertemuan ini, sehingga kualita dan hasil belajar siswa bisa lebih baik.

c. Evaluasi

Hasil evaluasi siklus II menunjukkan bahwa siswa yang memperoleh nilai minimal 63 adalah sebanyak 17 siswa atau sebesar $80,95 \%$ dengan nilai rata-rata 71,52 . Hal ini berarti hasil belajar siswa secara klasikal antara siklus I dan siklus II adalah sama yaitu 80,95\%. Namun demikian, secara rata-rata hasil belajar siswa mengalami peningkatan yaitu dari 69,42 pada siklus I, menjadi 71,52 pada siklus II.

\subsubsection{Tindakan Siklus III}

\section{a. Pertemuan Pertama}

Hasil analisis antara pengamat dan guru menunjukkan adanya perbedaan, yaitu pengamat menyatakan bahwa langkah yang dilakukan oleh guru hanya mencapai 20 langkah yang telah dilakukan, sedangkan menurut guru sendiri langkah yang telah dilakukan mencapai 21 langkah, sehingga terjadi perbedaan 1 langkah. Perbedaan yang dimaksud yaitu menurut hasil pengamat, guru tidak menyiapkan peserta didik secara psikis dan fisik untuk mengikuti proses pembelajaran tetapi menurut guru langkah ini sudah dilakukan.

Pengamat dan guru melakukan diskusi untuk menentukan atau mengambil keputusan langkah-langkah apa saja yang sebenarnya tidak dilakukan oleh guru, sehingga dari hasil diskusi tersebut dapat ditentukan langkah-langkah pembelajaran yang akan menjadi perbaikan pada pertemuan selanjutnya. Guru mencoba mengingat kembali tentang langkah ketika guru tidak menyiapkan peserta didik secara psikis dan fisik untuk mengikuti proses pembelajaran. Dari hasil renungannya guru merasa pada langkah ini guru telah menyiapkan peserta didik baik secara fisik maupun psikis untuk mengikuti proses pembelajaran. Hasil renungan guru tersebut kemudian didiskusikan dengan pengamat. Agar data lebih akurat, 
LA ODE SABRAN

UNIVERSITAS HALU OLEO

Ld.sabran@uho.ac.id

guru dan pengamat kemudian secara bersama-sama membandingkan data hasil perenungan

guru dan observasi pengamat dengan rekaman video yang dilakukan pada saat proses pembelajaran berlangsung. Setelah melakukan diskusi dan mengamati rekaman video pelaksanaan pembelajaran, maka disepakati bahwa langkah dimana guru menyiapkan peserta didik untuk mengikuti pembelajaran tidak dilakukan oleh guru, sehingga menjadi tujuan perbaikan pembelajaran pada pertemuan berikutnya. Langkah-langkah itu adalah:

1. Guru menyiapkan peserta didik secara psikis dan fisik untuk mengikuti proses pembelajaran.

2. Guru memberi kesempatan kepada siswa untuk memahami petunjuk dalam LKS mengenai pemanfaatan komputer sebagai media pembelajaran.

Hasil pengamatan observer dan guru pada pertemuan ini, menyimpulkan bahwa proses pembelajaran yang dilakukan dengan menerapkan komputer sebagai media pembelajaran sudah maksimal dilakukan oleh guru dan siswa, terlihat dari hasil diskusi antara guru dan pengamat yang mengungkapkan bahwa proses pembelajaran guru sudah mencapai 20 langkah pembelajaran yang terlaksana dari 22 langkah yang telah ditetapkan dan proses pembelajaran siswa mencapai $89,06 \%$. Hasil diskusi tersebut juga menunjukkan bahwa guru sudah dapat menerapkan pembelajaran dengan media komputer secara lebih baik tanpa ada kendala yang berarti. Walaupun pada pertemuan ini sudah sangat baik, guru merasa belum puas dan akan berusaha lebih baik lagi pada pertemuan berikutnya.

b. Pertemuan Kedua

Hasil analisis antara pengamat dan guru tidak ada perbedaan, yaitu pengamat mengatakan bahwa guru telah melakukan keseluruhan langkah-lankah pembelajaran sesuai dengan rencana perbaikan pembelajaran yang telah dibuat begitu pula hasil analisis guru.

Analisis deskriptif ketuntasan proses pelaksanaan pembelajaran oleh siswa untuk pertemuan kedua menurut hasil pengamatan observer menunjukkahn bahwa langkah-langkah pembelajaran yang dilakukan oleh siswa berdasarkan rencana pelaksanaan dan lembar observasi yang telah dibuat mencapai 90,62\% dari 16 langkah yang dilakukan oleh keseluruhan siswa. Meskipun hasil proses pembelajaran siswa belum tercapai secara keseluruhan, akan tetapi pembelajaran yang dilakukan oleh siswa sudah maksimal dan mencapai indikator yang telah ditetapkan dalam penelitian ini.

Pada pertemuan ini tidak ada perbedaan antara pengamat dengan guru dan terlihat bahwa pencapaian ketuntasan proses pembelajaran yang diamati oleh pengamat dan hasil jurnal refleksi guru untuk proses pembelajaran guru sudah mencapai hasil maksimal, begitu 
LA ODE SABRAN

UNIVERSITAS HALU OLEO

Ld.sabran@uho.ac.id

pula dengan pembelajaran siswa yang mencapai 90,62\%, sehingga indikator yang telah ditetapkan pada penelitian ini dari segi proses yaitu dikategorikan berhasil apabila minimal 85\% dari langkah-langkah pembelajaran terlaksana dengan baik oleh guru dan siswa telah tercapai. Bertitik tolak dari hasil yang diperoleh pada tindakan siklus III yakni dari segi proses telah mencapai indikator yang sudah ditetapkan serta karena materi pelajaran telah habis, maka penelitian ini dihentikan sampai pada siklus III. Dengan demikian hipotesis tindakan telah tercapai yakni hasil belajar matematika siswa kelas XII IPA SMA DDI Kendari pada materi ajar integral dapat di tingkatkan dengan menerapkan komputer (Software Derive 6.0) sebagai media pembelajaran.

c. Evaluasi

Berdasarkan hasil evaluasi siklus III menunjukkan bahwa hasil yang diperoleh telah memenuhi indikator kinerja yang sudah ditetapkan. Hasil belajar matematika siswa meningkat sebesar 9,52\% dari siklus II, yakni dari 80,95\% menjadi 90,47\%, dengan siswa yang memperoleh ketuntasan pembelajaran secara klasikal yaitu memperoleh nilai minimal 63 bertambah dari 17 siswa menjadi 19 orang siswa. Begitu pula nilai rata-rata siswa meningkat dari 71,52 menjadi 73,52.

\section{KESIMPULAN DAN SARAN}

\subsection{Kesimpulan}

Berdasarkan hasil pembahasan, maka dapat disimpulkan bahwa hasil belajar matematika siswa kelas XII IPA SMA Darul Da'wah Wal Irsyad Kendari pada materi pembelajaran integral dapat ditingkatkan melalui Penerapan Komputer (Software Derive 6.0) sebagai Media Pembelajaran. Hal ini dapat dilihat dari pencapaian indikator kinerja baik dari segi proses maupun dari segi hasil pada penelitian ini. Dari segi proses berkaitan dengan pelaksanaan rencana pelaksanaan/perbaikan pembelajaran oleh guru yang telah disusun dengan menerapkan komputer sebagai media pembelajaran pada siklus I mencapai 77,27\%, pada siklus II mencapai 90,9\% dan siklus III mencapai 100\%. Begitu pula dengan pelaksanaan pembelajaran yang dilakukan oleh siswa pada siklus I mencapai 85,93\%, pada siklus II mencapai 87,5\% dan siklus III mencapai 90,62\%. Dari segi hasil yang berkaitan dengan hasil belajar matematika siswa kelas XII IPA SMA DDI Kendari diperoleh hasil pada siklus I mencapai $80,95 \%$ atau sebanyak 17 orang dengan rata-rata 69,42, pada siklus II mencapai 80,95\% atau sebanyak 17 orang dengan nilai rata-rata 71,52, dan pada siklus III mencapai 90,47\% atau sebanyak 19 orang dengan nilai rata-rata 73,52. Pada siklus I dan II, 
LA ODE SABRAN

UNIVERSITAS HALU OLEO

Ld.sabran@uho.ac.id

ketuntasan pembelajaran siswa memiliki nilai yang sama, namun secara rata-rata hasil belajar siswa meningkat dari 69,42 menjadi 71,52. Secara umum hasil belajar siswa meningkat yaitu dari siklus I ketuntasan pembelajaran secara klasikal oleh siswa hanya mencapai $80,95 \%$ menjadi $90,47 \%$ pada siklus III.

\subsection{Saran}

Berdasarkan hasil kesimpulan, maka peneliti menyarankan bagi guru bidang studi matematika agar pembelajaran matematika dengan menerapkan komputer sebagai media pembelajaran dapat dilaksanakan lebih lanjut untuk meningkatkan hasil belajar matematika siswa khususnya dalam mengajarkan materi integral.

\section{DAFTAR PUSTAKA}

Abdurrahman, Mulyono. 2003. Pendidikan Bagi Anak Berkesulitan Belajar. Jakarta: Rineka Cipta.

Afgani, Muh. Winkel, dkk. 2008. Pengembangan Media Website Pembelajaran Materi Program Linear untuk Siswa Sekolah Menengah Atas. www.citejournal.org/articles/v7i4mathematics.pdf. (Diakses Tanggal 12 Mei 2011)

Ariani, Niken. 2010. Pembelajaran Multi Media di Sekolah. Jakarta: Prestasi Pustaka Publisher.

Emzir. 2003. Metodologi Penelitian Pendidikan Kuantitatif dan Kualitatif. Jakarta: Rajawali Pers.

Hadis, Abdul. 2010. Manajemen Mutu Pendidikan. Bandung: Alfabeta.

Hamalik, Oemar. 2003. Proses Belajar Mengajar. Jakarta: Bumi Aksara.

Hasibuan, dkk. 1986. Proses Belajar Mengajar Keterampilan Dasar Pengajaran Mikro. Bandung: Remaja Rosdakarya.

Hudoyo, Herman. 1988. Belajar Mengajar Matematika. Jakarta: Depdikbud Dirjen Dikti Proyek Pengembangan Lembaga Pendidikan Tenaga Kependidikan.

Indrayanto. 2011. Pengertian Proses Pembelajaran. http://id.shvoong.com/socialsciences/education/2043097-pengertian-proses-pembelajaran/\#ixzz1R5NctGK5

(Diakses, Tanggal 14 Juni 2011).

Muhidin, Sambas Ali. 2011. Kualitas Proses Pembelajaran. http://sambasalim.com/pendidikan/kualitas-proses-pembelajaran.html. (Diakses Tanggal 15 Juni 2011)

Purcell, J. Edwin dan Varberg, Dale. 1987. Kalkulus dan Geometri Analitis Jilid I. Jakarta: Erlangga. 
LA ODE SABRAN

UNIVERSITAS HALU OLEO

Ld.sabran@uho.ac.id

Sanaky, Hujair AH. 2011. Media Pembelajaran. Yogyakarta: Kaukaba.

Sardiman. 2007. Interaksi dan Motivasi Belajar Mengajar. Jakarta: Raja Grafindo Persada.

Semiawan, Conny R. 2002. Belajar dan Pembelajaran Pra-Sekolah dan Sekolah Dasar. Jakarta: Macan Jaya Cemerlang.

Simanjuntak, Lisnawaty, dkk. 1992. Metode Mengajar Matematika 1. Bandung: Rineka Cipta.

Slameto.1988. Belajar dan Faktor-faktor yang Mempengaruhinya. Jakarta: Bina Aksara.

Sukidin, dkk. 2008. Manajemen Penelitian Tindakan Kelas. Surabaya: Insan Cendekia.

Suryosubroto, B. 1993. Proses Belajar Mengajar di Sekolah. Jakarta: Rineka Cipta.

Thonthowi, Ahmad. 1993. Psikologi Pendidikan. Bandung: Angkasa.

Usman, Moh. Uzer. 2001. Upaya Optimalisasi Kegiatan Belajar. Bandung: Remaja Rosdakarya. 